\title{
Synthesis of 2-ethynyl-4(3H)quinazolinone and 2-(1,3-butadienyl)-4(3H)quinazolinone
}

\author{
Jan Bergman* and Ivan Romero \\ Department of Biosciences and Nutrition, Karolinska Institute, SE 14157 Huddinge, Sweden \\ E-mail:jan.bergman@ki.se
}

In honor of Prof. Henk van der Plas on the occasion of his 80th anniversary

\begin{abstract}
2-Ethynyl-4(3H)quinazolinone and 2-(1,3-butadienyl)-4(3H)quinazolinone have been synthesized by cyclizations from appropriate precursors. These two molecules are of interest as analogues of the known p-53 reactivator 2-vinyl-4(3H)quinazolinone.
\end{abstract}

Keywords: 2-Vinyl-4(3H)quinazolinone, cyclizations, Michael additions

\section{Introduction}

The tumor suppressor protein p-53 is expressed at low levels in most cells and tissues under normal conditions. Cellular stress such as DNA damage, oncogene activation induces p-53 protein levels, leading to an array of biological responses. The high frequency of p-53 mutations in human tumors, and the high levels of mutant p-53 expression in tumors makes p-53 an attractive target for novel cancer therapy. ${ }^{1}$ Several studies have demonstrated ways to restore normal function to mutant $\mathrm{p}-53$. $^{2}$

\section{Results and Discussion}

We have recently demonstrated that 2-vinyl-4(3H)quinazolinone (1) is a particularly interesting reactivator of $\mathrm{p}-53 .^{2}$ The effect is similar to, but stronger than, that of CP-31398, 2. More substituted derivatives of $\mathbf{1}$, such as $\mathbf{3}$, are considerably less active. With this background we considered it of interest to synthesize some related molecules, with a similarly low level of substitution, namely, $\mathbf{4}$ and $\mathbf{5}$. 
<smiles>C=Cc1nc2ccccc2c(=O)[nH]1</smiles>
1<smiles>C=C/C=C/c1nc2ccccc2c(=O)[nH]1</smiles>
4<smiles>NC(=O)c1ccccc1N</smiles>

6<smiles>COc1ccc(/C=C/c2nc3ccccc3/c(=N/CCCN(C)C)[nH]2)cc1</smiles><smiles>C#Cc1nc2ccccc2c(=O)[nH]1</smiles>

5

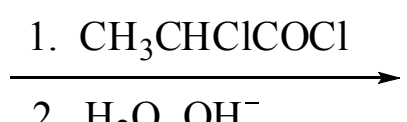

2. $\mathrm{H}_{2} \mathrm{O}, \mathrm{OH}^{-}$<smiles>C/C=C/c1nc2ccccc2c(=O)[nH]1</smiles>

3<smiles>C#Cc1nc2ccc(F)cc2c(=O)n1-c1ccccc1Cl</smiles>

13<smiles>C=Cc1nc2ccccc2c(=O)[nH]1</smiles>

\section{Scheme 1}

As compound $\mathbf{1}$ can be readily synthesized from 2-aminobenzamide, $\mathbf{6}$, on a large scale, as outlined in Scheme 1, ${ }^{3}$ this molecule was considered as an attractive precursor to $\mathbf{5}$. However, treatment of 1 with chlorine or bromine followed by conventional dihydrohalogenation was tried, but the outcome was erratic. At this point it was decided to prepare compound $\mathbf{4}$ before any approach to $\mathbf{5}$ would be tried. The required and known ${ }^{4,5}$ conjugated acid $\mathbf{7}$ and acid chloride $\mathbf{8}$ were prepared as outlined in Scheme 2. The final step leading to 4 was unproblematic.

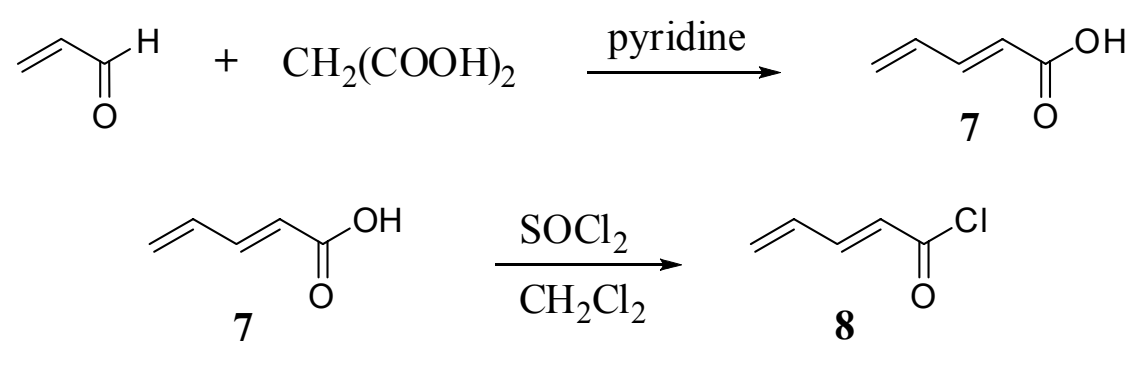

$$
8+6 \underset{2 . \mathrm{H}_{2} \mathrm{O}, \mathrm{OH}^{-}}{\frac{1 . \text { dioxane, } 75^{\circ} \mathrm{C} / 1 \mathrm{~h}}{\longrightarrow}}
$$

Scheme 2 
Compound 5, was then finally prepared similarly from propiolic acid $\mathbf{9}$, as outlined in Scheme 3. During the development of this procedure it was found that 2-aminobenzamide readily added to 5 in Michael fashion to give the adduct 11. In fact, this molecule could be obtained quickly, in quantitative yield, by heating equimolecular amounts of $\mathbf{5}$ and $\mathbf{6}$ in acetic acid. The vinyl derivative $\mathbf{1}$ gave the adduct 12 similarly (Scheme 4).

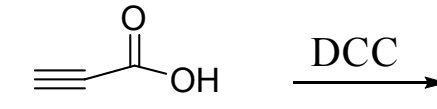

9

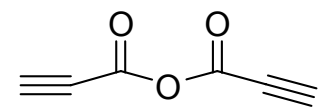

10<smiles>C#Cc1nc2ccccc2c(=O)[nH]1</smiles>

5

\section{Scheme 3}

The ethynyl derivative $\mathbf{5}$ is a new compound, and the only known somewhat- related molecule is the AMPA receptor inhibitor ${ }^{6}$ 13. $^{7}$ The atoms in the side-chain of molecule 5 feature some interesting couplings in the 2D- NMR HMBC spectrum which are as follows: ${ }^{1} J_{\mathrm{CH}}=256.3$ $\mathrm{Hz}$ and ${ }^{2} J_{\mathrm{CH}}=56.2 \mathrm{~Hz}$.<smiles>C#Cc1nc2ccccc2c(=O)[nH]1</smiles>

5<smiles>O=c1[nH]c(/C=C/F)nc2ccccc12</smiles>

1<smiles>NC(=O)c1ccccc1N</smiles>

6<smiles>NC(=O)c1ccccc1N</smiles>

6 $\underset{5 \min , 90{ }^{\circ} \mathrm{C}}{\stackrel{\mathrm{HOAc}}{\longrightarrow}}$<smiles>CC(C)O</smiles><smiles>NC(=O)c1ccccc1N/C=C/c1nc2ccccc2c(=O)[nH]1</smiles>

11<smiles>NC(=O)c1ccccc1NCCc1nc2ccccc2c(=O)[nH]1</smiles>

\section{Scheme 4}




\section{Conclusions}

Convenient procedures for 2-ethynyl-4(3H)quinazolinone $\mathbf{5}$ and 2-(1,3-butadienyl)4(3H)quinazolinone, 4, have been developed that will make them available for biological evaluations. Both compounds were found to be efficient acceptors for Michael additions.

\section{Experimental Section}

2,4-Pentadienoic acid (7). Malonic acid (21.1 g, $0.2 \mathrm{~mol})$ was stirred in pyridine $(25 \mathrm{~mL})$ at 40 ${ }^{\circ} \mathrm{C}$ until a clear solution was obtained, whereupon acrolein $(10 \mathrm{~mL})$ was added dropwise. The temperature rose to $60{ }^{\circ} \mathrm{C}$ and carbon dioxide was formed. A second addition of acrolein (10 $\mathrm{mL}$ ) was made when the evolution of gas has subsided and the temperature kept at $70-75{ }^{\circ} \mathrm{C}$ for $30 \mathrm{~min}$. The reaction was then poured into ice/water and the mixture was acidified with orthophosphoric acid, which resulted in partial precipitation of the title acid 7 as a solid, $8.5 \mathrm{~g}, \mathrm{mp}$. 71$71{ }^{\circ} \mathrm{C}$ (lit. ${ }^{4} \mathrm{mp} .71-72{ }^{\circ} \mathrm{C}$ ). The mother liquor was extracted with methylene chloride (3x) which upon drying and evaporation gave a second crop of 7, $5.5 \mathrm{~g}$. Total yield $14.0 \mathrm{~g}(72 \%)$. IR 29002500 (br), 1693, 1627, 1599, 1433, 1300, 1272, 1216, 1158, 1006, 928, $864 \mathrm{~cm}^{-1} ;{ }^{13} \mathrm{C} \mathrm{NMR} \delta$ : 123.1 (d), 125.5 (t), 132.7 (d), $143.9(\mathrm{~d}), 167.3$ (s).

2-(1,3-Butadienyl)-4(3H)quinazolinone (4). 2,4-Pentadienoic acid (8.2 g, $0.1 \mathrm{~mol})$ was dissolved in methylene chloride $(60 \mathrm{~mL})$, and thionyl chloride $(4.5 \mathrm{~mL})$ was added. After a period at reflux the solvent was evaporated and the residue dissolved in dioxane $(30 \mathrm{~mL}) ; 2-$ aminobenzamide $(13.6 \mathrm{~g}, 0.1 \mathrm{~mol})$ was added, and the mixture heated $\left(75^{\circ} \mathrm{C}, 1 \mathrm{~h}\right)$. After concentration, the residue was treated with water which resulted in the formation of an oil, which was dissolved in sodium hydroxide (aq, $8 \%, 60 \mathrm{~mL}$ ) and kept at $80{ }^{\circ} \mathrm{C}$ for $1 \mathrm{~h}$. This solution was allowed to cool and then acidified with acetic acid, to give the title compound as a white solid, $18.2 \mathrm{~g}(92 \%) \mathrm{mp} .136-137{ }^{\circ} \mathrm{C}$. IR $3184-2900$ (br), 1661, 1602, 1460, 1002, $766 \mathrm{~cm}^{-1} ;{ }^{13} \mathrm{C}$ NMR $\delta$ 121.0 (s), 124.3 (t), 124.9 (d), 125.7 (d), 126.3 (d), 127.0 (d), 134.3 (d), 135.6 (d), 139.0 (d), 148.8 (s), 151.2 (s), 161.7 (s). Anal: Calc. for $\mathrm{C}_{12} \mathrm{H}_{10} \mathrm{~N}_{2} \mathrm{O}, \mathrm{C} ; 72.71 ; \mathrm{H}, 5.09 ; \mathrm{N}, 14.13$, Found $\mathrm{C}$, 72.30; H, 5.00; N, 14.22 .

2-Ethynyl-4(3H)quinazolinone (5). Propiolic acid $(5.4 \mathrm{~g}, 0.1 \mathrm{~mol})$ was added to dicyclohexylcarbodiimide $(20.6 \mathrm{~g}, 0.1 \mathrm{~mol})$ in tetrahydrofuran $(100 \mathrm{~mL})$. A precipitate was formed and 2aminobenzamide $(13.6 \mathrm{~g}, 0.1 \mathrm{~mol})$ was added. After a period at reflux $(30 \mathrm{~min})$ the mixture was allowed to cool, the precipitate of dicyclohexylurea was removed, and the residue was concentrated, and a solution $(8 \%)$ of sodium hydroxide $(60 \mathrm{~mL})$ was added. After heating at 80 ${ }^{\circ} \mathrm{C}$ for $1 \mathrm{~min}$, the mixture was allowed to cool. Acidification with acetic acid gave the title compound, $11.5 \mathrm{~g} \mathrm{(68 \% ),} \mathrm{mp} 160{ }^{\circ} \mathrm{C}$ dec. IR 3220-2700 (br), 2114, 1672 (s), 1587, 1465, 1273, 1256, 994, 869, $769 \mathrm{~cm}^{-1}$; ${ }^{1} \mathrm{H}$ NMR $\delta 4.69(\mathrm{~s}), 7.511(\mathrm{dd}), 7.63(\mathrm{~d}), 7.95(\mathrm{dd}), 8.11(\mathrm{dd}), 12.8(\mathrm{~s}$, br), ${ }^{13} \mathrm{C}$ NMR $\delta 77.0$ (d), 82.4 (s), 122.2 (s), 125.8 (d), 127.2 (d), 127.5 (d), 134.5 (d), 137.6 (s), 
148.1 (s), 160.9 (s). Anal: Calc. for $\mathrm{C}_{10} \mathrm{H}_{6} \mathrm{~N}_{2} \mathrm{O}, \mathrm{C}, 70.57$; H, 3.55, N, 16.46; Found C, 70.30; H, $3.68, \mathrm{~N}, 16.26$.

The adduct 11. 2-Ethynyl-4(3H)quinazolinone (170 $\mathrm{mg}, 1 \mathrm{mmol})$ and 2-aminobenzamide (136 $\mathrm{mg}, 1 \mathrm{mmol})$ in acetic acid $(8.0 \mathrm{~mL})$ were heated on a water-bath for $5 \mathrm{~min}$. The precipitate obtained was collected, washed with methanol, and dried, $306 \mathrm{mg}(100 \%) \mathrm{mp} .>260{ }^{\circ} \mathrm{C}$. IR $3368,3110-2970,1672,1634,1605,1582,1519,1274,966,838,766,743 \mathrm{~cm}^{-1} ;{ }^{1} \mathrm{H}$ NMR $\delta: 5.19$ (d, 1H, CH, J=8.75), 6.99 (m, 1H, CH, $\left.\mathrm{J}_{1}=8.75, \mathrm{~J}_{2}=12.5\right), 7.35$ (dd, 1H, CH), 7.45-8.20 (m, 10H, $\left.8 \mathrm{CH}+\mathrm{NH}_{2}\right), 11.9(\mathrm{~s}, 1 \mathrm{H}, \mathrm{NH}), 12.7(\mathrm{~d}, 1 \mathrm{H}, \mathrm{NH}, \mathrm{J}=12.5) .{ }^{13} \mathrm{C} \mathrm{NMR} \delta: 90.9$ (d), 114.2 (d), 119.6 (s), 120.6 (d), 121.1 (s), 124.5 (d), 125.4 (d), 126.7 (d), 129.0 (d), 132.1 (d), 133.9 (d), 138.3 (d), 141.2 (s), 149.6 (s), 153.5 (s), 161.7 (s), 170.0 (s). Anal: Calc. for $\mathrm{C}_{17} \mathrm{H}_{14} \mathrm{~N}_{4} \mathrm{O}_{2}, \mathrm{C}, 66.65$; $\mathrm{H}$. 4.61; N, 18.29, Found C, 66.35; H, 4.73, N, 18.08.

The adduct 12. 2-Vinyl-4(3H)quinazolinone (172 $\mathrm{mg}, 1 \mathrm{mmol})$ and 2-aminobenzamide (136 $\mathrm{mg}, 1 \mathrm{mmol})$ in acetic acid $(8.0 \mathrm{~mL})$ was heated on a water-bath for $5 \mathrm{~min}$. the precipitate obtained was collected, washed with methanol and dried, $308 \mathrm{mg}(100 \%) \mathrm{mp}$. $>260{ }^{\circ} \mathrm{C}$. IR 3429 , 3296, 3040, 2760, 1690, 1672, 1647, 1611, 1578, 1515, 1470, 1281, 1186, 911, $878 \mathrm{~cm}^{-1} ;{ }^{1} \mathrm{H}$ NMR $\delta: 2.91\left(\mathrm{t}, 2 \mathrm{H}, \mathrm{CH}_{2}\right), 3.60\left(\mathrm{~m}, 2 \mathrm{H}, \mathrm{CH}_{2}\right), 6.53(\mathrm{dd}, 1 \mathrm{H}, \mathrm{CH}), 6.79(\mathrm{~d}, 1 \mathrm{H}, \mathrm{CH}), 7.15$ (br, s, $1 \mathrm{H}, \mathrm{NH}), 7.25(\mathrm{dd}, 1 \mathrm{H}, \mathrm{CH}), 7.46(\mathrm{dd}, 1 \mathrm{H}, \mathrm{CH}), 7.57$ (dd, 1H, CH), $7.65(\mathrm{~m}, 2 \mathrm{H}, \mathrm{CH}+\mathrm{NH}), 7.75$ $(\mathrm{m}, 2 \mathrm{H}, \mathrm{CH}+\mathrm{NH}), 8.07(\mathrm{~d}, 1 \mathrm{H}, \mathrm{CH}), 8.33(\mathrm{t}, 1 \mathrm{H}, \mathrm{NH}), 12.3(\mathrm{br}, \mathrm{s}, 1 \mathrm{H}, \mathrm{NH}) .{ }^{13} \mathrm{C} \mathrm{NMR} \delta 34.2(\mathrm{t})$, 39.6 (t), 111.1 (d), 114.1 (s), 114.2 (d), 120.9 (s), 125.7 (d), 126.1 (d), 126.9 (d), 129.1 (d), 132.6 (d), 134.3 (d), 148.8 (s), 149.4 (s), 155.5 (s), 161.8 (s), 171.5 (s).

\section{References and Notes}

1. Vogelstein, B.; Lane, D.; Levine, A. J. Nature 2000, 408, 307.

2. Zache, N.; Lambert, J. M. R.; Rökaeus, N.; Shen, J.; Hainaut, P.; Bergman, J.; Wiman, K. G.; Bykov, V. J. N. Molecular Oncology 2008, 2, 70.

3. Witt, A.; Bergman, J. Tetrahedron 2000, 56, 7245.

4. Idoux, J. P.; Ghane, H. J. Chem. Eng. Data 1979, 24, 157.

5. Jessup, J. P.; Petty, C. B.; Roos, J.; Overman, L. E. Org. Synth. 1980, 59, 1.

6. Chenard, B. L.; Welch, W. M.; Blake, J. F.; Butler, T. W.; Reinhold, A.; Ewing, F. E.; Menniti, F. S.; Pagnozzi, M. J. J. Med. Chem. 2001, 44, 1710.

7. Still another 2-phenylethynyl derivative, namely 6-chloro-2-phenylethynyl-4(3H)quinazolinone, has been briefly mentioned in the literature (with no chemical data). ${ }^{8}$

8. Jiang, J. B.; Hesson, B. A.; Dusak, D. L.; Dexter, G. J.; Kang, G. J.; Hamel, E. J. Med. Chem. 1990, 33, 1721. 